\title{
Efektivitas Penerapan Model Problem Based Learning Terhadap Peningkatan Hasil Belajar Bola Voli
}

\section{The Effectiveness of Implementing Problem Based Learning Models on Improving Volleyball Learning Outcomes}

\author{
Budi Priyadi ${ }^{1}$ \\ ${ }^{1}$ MTs Negeri 5 Kuningan, Kuningan, Indonesia \\ email: budipriyadi@gmail.com¹ \\ do: \\ : https://doi.org/10.20884/1.paju.2021.3.1.4774
}

\begin{abstract}
Abstrak
Penelitian ini dilatarbelakangi oleh siswa yang kesulitan untuk memecahkan permasalahan teknik dasar service dalam pembelajaran bola voli. Kurikulum 2013 menganjurkan menerapkan sebuah model pembelajaran dengan pendekatan saintifik. Tujuan dari penelitian ini adalah untuk memperbaiki hasil belajar siswa pada materi permainan bola voli teknik dasar service dengan menggunakan model problem based learning (PBL). Metode yang digunakan dalam penelitian ini adalah Penelitian Tindakan Kelas (PTK). Populasi sebanyak 1025 siswa MTs Negeri 5 Kuningan, sedangkan sampel 32 siswa kelas IX.2. Teknik pengambilan sampel adalah purposive sampling. Instrumen penelitian yaitu tes service bola voli. Analisis data penelitian menggunakan analisis deskriptif kuantitatif dengan ms. Excel untuk mengetahui peningkatan keterampilan service disetiap siklus Penelitian Tindakan Kelas. Hasil penelitian menunjukkan bahwa dengan menerapkan model PBL secara signifikan dapat meningkatkan hasil belajar teknik dasar service bola voli. Penelitian lebih lanjut bisa menggunakan model pembelajaran saintifik lainnya sebagai bahan perbandingan terhadap efektivitas hasil belajar permainan bola voli.
\end{abstract}

Kata Kunci: Bola Voli, Model Pembelajaran, Kurikulum 2013; Pendekatan Saintifik; Problem Based Learning

\begin{abstract}
This research is motivated by students who have difficulty solving basic service technical problems in volleyball learning. The 2013 curriculum recommends applying a learning model with a scientific approach. The purpose of this study was to improve student learning outcomes in volleyball game material with basic service techniques using a problem based learning (PBL) model. The method used in this research is Classroom Action Research (CAR). The population is 1025 students of MTs Negeri 5 Kuningan, while the sample is 32 students of class IX.2. The sampling technique is purposive sampling. The research instrument is volleyball service test. Analysis of research data using descriptive quantitative analysis with $\mathrm{ms}$. Excel to find out the improvement of service skills in every cycle of Classroom Action Research. The results showed that applying the PBL model could significantly improve the learning outcomes of volleyball
\end{abstract}


service basic techniques. Further research can use other scientific learning models as a comparison material for the effectiveness of volleyball learning outcomes.

Keywords: Curriculum 2013, Learning Model, Problem Based Learning, Scientific Approach, Volleyball

\section{PENDAHULUAN}

Kegiatan proses pembelajaran masa kini dibingkai melalui kurikulum 2013 menggunakan pendekatan ilmiah sebagai penerapan berbagai model pembelajaran scientific seperti model Problem Based Learning (PBL), Project Based Learning (PJBL), inquiry, dan discover learning. Model-model pendekatan scientific tersebut diharapkan dapat menumbuhkembangkan kreativitas, cara berpikir kritis, kolaborasi, dan komunikasi. Penelusuran tentang pencarian kebenaran dari aktivitas pembelajaran melalui pendekatan ilmiah tentunya lebih sistematis, siswa belajar bagaimana memecahkan masalah, merumuskan permasalahan, menyusun kerangka teori, menyusun hipotesis, menguji hipotesis, sampai dengan membuat suatu kesimpulan (Kemendikbud, 2013).

Model pembelajaran scientific dalam kurikulum 2013 yang digunakan pada mata pelajaran Pendidikan Jasmani Olahraga dan Kesehatan (PJOK) salah satunya yaitu problem based learning. Seperti namanya model ini lebih menitikberatkan bagaimana siswa belajar memecahkan permasalahan.Awalnya model ini dikembangkan di fakultas kedokteran Kanada pada tahun (Barrows, 1996). Model PBL diperuntukan menjawab respon tentang aspek pengetahuan yang luarbiasa dari para dokter muda di fakultas tersebut, namun dari segi implementasi kontekstual di lapangan perlu mendapatkan pengalaman keterampilan yang baik. Oleh karena itu model PBL lahir sebagai salah satu alternatif untuk memfasilitasi tranfer pengetahuan kedalam praktik dalam kehidupan sehari-hari. Seiring perkembangan zaman, kini model PBL digunakan diberbagai perguruan tinggi dalam proses perkuliahan, dan juga digunakan di berbagai sekolah untuk proses pembelajaran tiap mata pelajaran (Kemendikbud, 2013).

Model problem based learning diciptakan berlandaskan teori pembelajaran inovatif seperti teori konstruktivisme dan kontekstual learning dengan menyuguhkan sebuah permasalahan untuk diselesaikan melalui adegan pembelajaran. PBL dapat digunakan oleh guru pendidikan jasmani dalam rangka membantu siswa untuk memecahkan permasalahan yang sengaja dibuat, sehingga diharapkan keterampilan pemecahan 
Budi Priyadi | Efektivitas Penerapan Model Problem Based Learning Terhadap Peningkatan Hasil Belajar Bola Voli

masalah tersebut berimplikasi dalam kehidupannya kelak (Mayasari, Kadarohman, Rusdiana, \& Kaniawati, 2016). Edens (2000) menjelaskan model PBL dapat membekali siswa mempunyai keterampilan pada abad 21.

PBL merupakan sebuah model pembelajaran dengan memberikan permasalahan praktis kepada siswa yang dikaitkan dengan dunia yang sebenarnya (Tan, 2003;Wee Keng, 2002). Model PBL ini membantu siswa untuk melatih keterampilan dalam hal memecahkan permasalahan di dalam kelas dengan mengembangkan pengetahuan yang dimilikinya. Proses pembelajaran dengan menggunakan PBL akan membentuk pengetahuan baru siswa yang lebih bermanfaat.

Para peneliti pendidikan berpendapat model PBL dapat meningkatkan keterampilan berpikir kritis siswa, karena mampu menghubungkan antara teori dan praktik dan mampu mengembangkan keterampilan dalam memecahkan masalah, kokunikasi, dan kolaborasi (Graham, 2010, 2012). Hasil penelitian yang dilakukan oleh Woods (1996) mengemukakan bahwa penerapan PBL dapat meningkatkan persepsi positif siswa dalam pembelajran, memiliki kepercayaan diri lebih baik karena disuguhkan untuk memecahkan permasalahan, meningkatkan sikap positif selama pembelajaran berlangsung, dan memiliki keterampilan proses yang lebih baik.

Model PBL berdasarkan beberapa dari hasil penelitian dapat melatih keterampilan siswa abad 21 di era globalisasi (Wagner, 2008;Slough, S. W., \& Milam, 2013). Haigt, W., Kelly, R. , \& Bogda, (2005) mengungkapkan bahwa penerapan model PBL dalam pembelajaran dapat meningkatkan keterampilan berpikir tingkat tinggi (analisis, sintesis, dan evaluasi). Penelitian lain yang dilakukan oleh EdVisions, (2007) menunjukkan dengan menerapkan model PBL secara signifikan dapat meningkatkan keetrampilan abad 21, meningkatkan konsep diri siswa serta dapat meningkatkan keterampilan berpikir tingkat tinggi.

Terdapat beberapa manfaat dari penerapan model PBL dalam kegiatan belajar mengajar Amir, (2009) diantaranya; 1) meningkatkan keterampilan siswa dalam memecahkan permasalahan di kelas. 2) meningkatkan daya ingat siswa terhadap materi yang sudah dipelajari. 3) meningkatkan siswa dalam memahami isi materi pelajaran. 4) meningkatkan keterampilan mengaitkan relevansi teori dengan praktik. 5) membangun jiwa leadership dan kolaboratif. 6) meningkatkan kecakapan belajar, motivasi, dan menumbuhkembangkan daya kreasi berpikir tingkat tinggi siswa. 
Pendidikan jasmani merupakan pendidikan melalui aktivitas jasmani yang didalamnya mengajarkan tentang aktivitas fisik, keterampilan gerak, integrasi sosial, dan perkembangan psikologis. Muara pendidikan jasmani sama halnya dengan mata pelajaran lainnya yaitu dari UUSPN nomor 20 tahun 20013 dengan tujuan menyentuh aspek kognitif, afektif, dan psikomotor. Kurikulum 2013 menjelaskan bahwa pendekatan yang digunakan untuk pembelajaran berorientasi terhadap pendekatan ilmiah. Penerapan model berbasis masalah dapat dijadikan salah satu panduan dalam rangka meningkatkan siswa terhadap pemecahan masalah (Depdiknas RI, 2003).

Mata Pelajaran PJOK bertujuan untuk meningkatkan kemampuan fisik, keterampilan gerak, aspek sosial, dan aspek psikologis (Suherman, 2009). Pendidikan jasmani memberikan dan menumbuhkembangkan anak menjadi pribadi yang cakap, melatih jiwa sportifitas, fair play, kesadaran berperilaku hidup sehat, memiliki kecakapan akademik, dan kecakapan sosial (Yudiana, 2015). Kurikulum pendidikan jasmani di sekolah menjabarkan tujuh aktivitas yang harus dipelajari siswa, diantaranya; 1) Aktivitas permainan dan olahraga; 2) Aktivitas pengembangan; 3) Uji diri/senam; 4) Aktivitas ritmik; 5) Aktivitas air atau aquatik; 6) Pendidikan luar kelas; dan 7) pendidikan kesehatan (Depdiknas RI, 2003).

Pembelajaran permainan bola voli adalah salah satu materi yang diberikan kepada siswa SMP/MTs dan termasuk bagian dari aktivitas permainan olahraga bola besar. Kompetensi dasar aspek pengetahuan yang harus dimiliki yaitu siswa memahami gerak spesifik dalam berbagai permainan bola besar sederhana dan atau tradisional, dan aspek ketrampilan mempraktikkan gerak spesifik dalam berbagai permainan bola besar sederhana dan atau tradisional. Materi pokok permainan bola voli diantaranya; 1) Passing bawah, 2) Passing atas, 3) Servis bawah, 4) Servis atas, 5) Smash/spike, dan 6) Block/ bendungan (Kemendikbud, 2017).

Indikator-indikator ini lah yang harus mendapatkan perhatian dari guru PJOK agar semua kompetensi dasar dan tujuan pembelajaran dalam permainan bola voli dapat dicapai oleh siswa. Indikator keberhasailan belajar dapat terealisasi dengan baik ditunjang dengan kreativitas guru itu sendiri dalam memilih model pembelajaran yang tepat. Kurikulum 2013 menawarkan beberapa model pembelajaran saintifik, salah satunya dengan menerapkan model problem-based learning.

Dalam pembelajaran permainan bola voli yang dilaksanakan di MTs Negeri 5 Kuningan kelas IX tentunya menghadapi beberapa permasalahan, diantaraya siswa 
Budi Priyadi | Efektivitas Penerapan Model Problem Based Learning Terhadap Peningkatan Hasil Belajar Bola Voli

kesulitan dalam memecahkan masalah bagaimana untuk melakukan teknik dan gerak passing bawah, passing atas, dan service yang baik, sehingga berdampak terhadap nilai KKM. Adapun nilai KKM untuk mata pelajaran PJOK di MTs Negeri 5 Kuningan adalah 75. Melihat kondisi demikian nampaknya harus ada solusi yang dapat meningkatkan keterampilan siswa dalam memecahkan masalah teknik dasar bola voli. Dari beberapa liteartur dan hasil penelitian yang sudah dijelaskan sebelumnya model PBL merupakan solusi yang tepat agar keterampilan siswa dalam memecahkan permasalahan teknik dasar bola voli dapat meningkat, dan berimplikasi terhadap capaian KKM.

Penelitian yang dilakukan Suzianto \& Damanik (2014) menyatakan bahwa penerapan model Problem Based Learning dapat meningkatkan hasil belajar passing bawah bola voli pada siswa kelas VIII-2 SMP Negeri 27 Medan T.P 2018/2019. Penelitian lain yang dilakukan Prayoga (2021) menemukan bahwa peningkatan hasil belajar passing atas dan passing bawah melalui model pembelajaran Problem Based Learning di SMAN 15 Semarang dikarenakan dalam penggunaan model pembelajaran ini siswa diberi kebebasan dalam belajar. Penelitian yang kami lakukan adalah bagaimana penerapan model problem based learning untuk meningkatkan hasil belajar tektik dasar service dalam permainan bola voli.

Model PBL nampaknya baru digunakan dalam pembelajaran pendidikan jasmani yang terstruktur khususnya pada materi permainan bola voli. Penelitian yang dilakukan oleh Hamzah \& Hadiana (2018) tentang penerapan model PBL dalam meningkatkan hasil belajar passing futsal, dan hasil penelitian menunjukkan bahwa model PBL dapat meningkatkan keterampilan passing siswa. Penelitian yang penulis lakukan merupakan penelitian tindakan kelas dalam rangka untuk memperbaiki hasil belajar siswa pada materi permainan bola voli dengan menggunakan model PBL.

\section{METODE}

Metode yang digunakan dalam penelitian ini adalah jenis Penelitian Tindakan Kelas (PTK). Penelitian Tindakan Kelas (PTK) adalah penelitian tindakan yang dilakukan oleh guru dengan tujuan untuk memperbaiki mutu pelaksanaan pembelajaran di kelasnya (Arikunto, 2010). Alur penelitian dalam PTK direpresentasikan melalui tahapan siklus mulai dari perencanaan, pelaksanaan, pengamatan dan refleksi. Rangkaian siklus dalam penelitian ini diilustrasikan pada gambar 1 dibawah ini: 


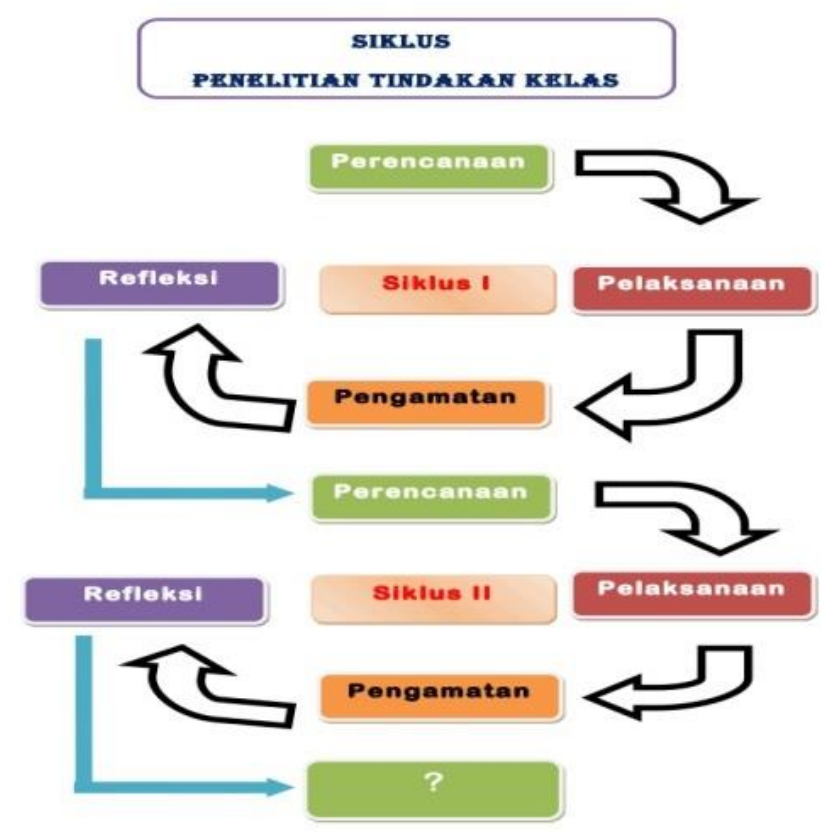

Gambar 1. Siklus Penelitian Tindakan Kelas

Populasi penelitian yaitu siswa MTs Negeri 5 Kuningan dengan jumlah 1.025 orang, sedangkan sampel penelitian yaitu kelas IX.2 dengan jumlah 32 siswa. Teknik pengambilan sampel menggunakan purposive sampling karena bertujuan untuk memperbaiki proses pembelajaran di kelas tersebut (Sugiyono, 2013). Instrumen yang digunakan untuk mengukur keterampilan teknik dasar service bola voli adalah tes keterampilan service bola voli (Nurhasan, 2007). Teknik analisis data dalam penelitian tindakan kelas ini menggunakan data kuantitatif dan kualitatif.

\section{a. Data kuantitatif}

Data kuantitatif berupa hasil belajar keterampilan service bola voli dianalisis secara deskriptif mengacu terhadap nilai KKM dan nilai rata-rata kelas. Penyajian data dipaparkan dalam bentuk persentase dan angka sesuai dengan keterangan yang disampaikan Aqib (2010).

Berdasarkan ketentuan juknis pelaksanaan pembelajaran, peneliti berkeyakinan dengan menerapkan model problem based learing dalam pembelajaran pendidikan jasmani materi permainan bola voli dapat memenuhi batas minimal ketuntasan belajar sebesar 75 dari hasil tes yang dilakukan oleh siswa baik itu penilaian proses dan nilai 
Budi Priyadi | Efektivitas Penerapan Model Problem Based Learning Terhadap Peningkatan Hasil Belajar Bola Voli

produk.Perhitungan persentase dalam menentukan ketuntasan belajar siswa, dapat kita lihat pada rumus sebagai berikut:

$\mathrm{P}=\frac{\sum \text { Siswayangtuntasbelajar }}{\sum \text { Siswa }} X 100 \%$

Penentuan presentase menggunakan rumus tersebut perlu dilihat berdasarkan nilai kriteria ketuntasan belajar siswa Kelas IX MTs Negeri 5 Kuningan yang dikelompokkan ke dalam dua kategori yaitu tuntas dan tidak tuntas dengan kriteria:

Tabel 1.KKM Mata Pelajaran PJOK

\begin{tabular}{cc}
\hline Kriteria Ketuntasan & Kualifikasi \\
\hline$\geq 75$ & Tuntas \\
$<75$ & Tidak Tuntas \\
\hline
\end{tabular}

Sumber: KKM siswa kelas IX MTs Negeri 5 Kuningan

Adapun Rumus dalammenentukan nilai rata-rata siswa dapat dilihat di bawah ini:

$X=\frac{\sum X}{\sum N}$

Keterangan:

$\mathrm{x}=$ Nilai rata-rata

$\sum \mathrm{X}=$ Jumlah semua nilai siswa

$\sum N=$ Jumlah siswa

b. Data kualitatif

Penelitian tindakan kelas yang kami lakukan terdiri dari data kualitatif dan kuantitatif.

Data kualitatif terdiri diperoleh dari hasil belajar permainan bola voli. Data kualitatif dideskripsikan dengan kalimat menurut kategori sehingga memperoleh sebuah kesimpulan. Adapun data hasil belajar siswa yang dianalisis menggunakan pendekatan kualitatif untuk mendapatkan kesimpulan dapat dilihat pada tabel berikut:

Tabel 2.Kriteria keberhasilan belajar siswa

\begin{tabular}{cll}
\hline $\begin{array}{c}\text { Rentang Capaian } \\
\text { Pembelajaran }\end{array}$ & \multicolumn{1}{c}{ Kategori } & \multicolumn{1}{c}{$\begin{array}{c}\text { Tingkatan Keberhasilan } \\
\text { Belajar }\end{array}$} \\
\hline $85-100 \%$ & Sangat Baik (SB) & Berhasil \\
$65-84 \%$ & Baik (B) & Berhasil \\
$55-64 \%$ & Cukup (C) & Tidak Berhasil \\
$0-54 \%$ & Kurang (K) & Tidak Berhasil \\
\hline
\end{tabular}

Sumber: (Aqib, 2010) 
Analisis data pada tahap ini digunakan pada saat refleksi. Hasil dari analisis ditindaklanjuti sebagai bahan perbaikan dalam merumuskan perencanaan pada siklus berikutnya. Hasil analisis juga dapat menjadi sebuah evaluasi dalam menentukan skema dalam memperbaiki pembelajaran atau bahkan dapat menjadi bahan pertimbangan dalam memilih model pembelajaran yang tepat sesuai dengan permasalahan yang terjadi di lapangan.

\section{HASIL}

Data penelitian yang diperoleh berupa data hasil pengamatan dalam proses pembelajaran untuk masing-masig siklus. Data lembar observasi diambil dari observasi terhadap tindakan siswa dalam proses pembelajaran yang digunakan untuk mengetahui proses penerapan model PBL untuk meningkatkan hasil belajar permainan bola voli. Dengan menggunakan instrument tes keterampilan teknik dasar service bola voli, peneliti menilai pelaksanaan tindakan dalam rangka peningkatan hasil belajar bola voli selama 4 kali pertemuan yang terbagi dalam 2 siklus. Untuk selanjutnya, data hasil tes ini di bagi persiklus. Analisis dan refleksi untuk menentukan tindakan perbaikan. Sebaiknya untuk mengetahui peningkatan hasil belajar bola voli, berikut ini di tampilkan data hasil tes di lapangan.

Untuk menentukan kriteria keberhasilan tindakan dalam rangka peningkatan hasil belajar bola voli melalui model PBL, data hasil tes setiap siklus kita tabulasikan kemudian dianalisis dengan mean. Hasil rata-rata kedua siklus lalu kita bandingkan untuk mengetahui perkembangan mutu tindakan. Guna memperjelas hasil analisis dan memudahkan interpretasi, data peningkatan mutu tindakan akan ditampilkan dalam bentuk diagram batang. Analisis data selengkapnya sebagai berikut.

Tabel 3. Analisis Hasil Tes Keterampilan Teknik Dasar Service Bola Voli Siklus I Kelas IX.2 MTs Negeri 5 Kuningan

\begin{tabular}{|c|c|c|c|c|c|}
\hline & \multicolumn{2}{|c|}{ Aspek yang Dinilai } & \multirow[b]{2}{*}{$\begin{array}{l}\text { Jml. } \\
\text { Skor }\end{array}$} & \multicolumn{2}{|c|}{ Ketuntasan } \\
\hline & $\begin{array}{c}\text { Proses } \\
(70 \%)\end{array}$ & $\begin{array}{c}\text { Produk } \\
(30 \%)\end{array}$ & & Tuntas & $\begin{array}{l}\text { Tidak } \\
\text { Tuntas }\end{array}$ \\
\hline Jumlah & & & 2305 & 19 & 13 \\
\hline Rata-rata & & & 72 & & \\
\hline
\end{tabular}


Budi Priyadi | Efektivitas Penerapan Model Problem Based Learning Terhadap Peningkatan Hasil Belajar Bola Voli

Dari hasil tabel 3 diatas dapat diketahui nilai rata - rata hasil tes keterampilan teknik dasar bola voli adalah 72 . Sedangkan batas KKM adalah 75 sehingga perlu dilanjutkan ke siklus yang kedua. Hasil tes siklus ke II dapat dilihat pada tabel 4 dbaah ini.

Tabel 4. Analisis Hasil Tes Keterampilan Teknik Dasar Service Bola Voli Siklus II Kelas IX.2 MTs Negeri 5 Kuningan

\begin{tabular}{lccccc}
\hline & \multicolumn{2}{c}{ Aspek yang Dinilai } & & & \multicolumn{2}{c}{ Ketuntasan } \\
& $\begin{array}{c}\text { Proses } \\
(\mathbf{7 0 \% )}\end{array}$ & $\begin{array}{c}\text { Produk } \\
(\mathbf{3 0 \% )}\end{array}$ & Skor & Tuntas & $\begin{array}{c}\text { Tidak } \\
\text { Tuntas }\end{array}$ \\
\hline Jumlah & & & 2650 & 32 & - \\
\hline Rata-rata & & & 83 & & \\
\hline
\end{tabular}

Dari hasil tabel 4 diatas dapat diketahui nilai rata - rata hasil tes keterampilan teknik dasar sepak bola adalah 83. Sedangkan batas KKM adalah 75 sehingga tidak perlu dilanjut ke siklus berikutnya karena sudah memenuhi KKM. Selnjutnya merupakan perbandingan hasil tes Teknik dasar service pada siklus I dan II yang terlihat pada tabel 5 dibawah ini.

Tabel 5.Analisis Perbandingan Hasil Nilai Tindakan Siklus I dan siklus II Kelas IX.2 MTs Negeri 5 Kuningan

\begin{tabular}{lccl}
\hline & Siklus I & Siklus II & Keterangan \\
\hline Jumlah & 2305 & 2650 & \\
Rata-rata & 72 & 83 & Terdapat Peningkatan \\
\hline
\end{tabular}

Data peningkatan hasil belajar bola voli dicermati dengan dua tujuan, yaitu: untuk mengetahui penguasaan materi bola voli secara umum melalui analisis persentase ketuntasan belajar dan untuk mengetahui peningkatan hasil belajar siswa melalui model problem-based learning.

Tabel 6. Hasil Analisis Ketuntasan Belajar (KKM $\geq 75)$

\begin{tabular}{ccc}
\hline Siklus & Jumlah Siswa Tuntas Belajar & Persentase (\%) \\
\hline$I$ & 19 & 59 \\
II & 32 & 100 \\
\hline
\end{tabular}

Tabel 6 menjelaskan bahwa peningkatan hasil belajar bola voli siswa kelas IX.2MTs Negeri5Kuningan tampak bahwa prosentase ketuntasan belajar pada siklus I ke siklus || mengalami peningkatan yang tinggi yaitu dari $59 \%$ menjadi $100 \%$. 


\section{PEMBAHASAN}

Pembelajaran berbasis masalah adalah pembelajaran yang menggunakan masalah nyata yang tidak terstruktur (ill-structured) dan bersifat terbuka (open-ended) sebagai konteks atau sarana bagi peserta didik untuk mengembangkan keterampilan menyelesaikan masalah dan berpikir kritis serta membangun pengetahuan baru. Berbeda dengan pembelajaran konvensional yang menjadikan masalah nyata, dalam bentuk soal cerita, sebagai penerapan dari konsep atau pengetahuan yang telah dipelajari, pembelajaran berbasis masalah menggunakan masalah nyata di awal tahap pembelajaran sebagai sarana bagi peserta didik untuk membangun pengetahuannya(Depdikbud, 2003).

Dalam pembelajaran berbasis masalah, peserta didik, secara individual maupun berkelompok, menyelesaikan masalah nyata tersebut dengan menggunakan strategi atau pengetahuan yang telah dimiliki. Secara kritis, peserta didik menginterpretasikan masalah, mengidentifikasi informasi dan strategi yang diperlukan, menemukan dan mengidentifikasi solusi yang mungkin, mengevaluasi kesesuaian strategi dan solusi, dan mengkomunikasikan simpulan. Proses tersebut memungkinkan peserta didik berlatih mengembangkan kemampuan berpikir kritis dan kemampuan menyelesaikan masalah serta membangun konsep, pengetahuan, atau strategi tertentu. Proses pembelajaran demikian sejalan dengan paham konstruktivisme yang menekankan peserta didik untuk secara aktif membangun pengetahuannya sendiri, bukan menerimanya dalam bentuk jadi dari guru (Depdikbud, 2003).

Problem based learning merupakan sebuah model pembelajaran dengan menyuguhkan permasalahan kepada siswa untuk dapat dipecahkan memlalui adegan pembelajaran sehingga memperoleh pengetahuan baru (Muhson, 2009). Penelitian lain yang dilakukan oleh Ejin (2016) menemukan bahwa model PBL melatih siswa untuk memecahkan permasalahan dalam kehidupan nyata (kontekstual) melalui pembelajaran di kelas, sehingga membekali siswa untuk berpikir kritis.

Pembelajaran permainan bola voli yang dilakukan siswa kelas IX.2 MTs Negeri 5 Kuningan dengan menggunakan model PBL membekali siswa untuk lebih percaya diri, karena materi pelajaran didesain yang memungkinkan anak mencari solusi dari berbagai permasalahan yang sengaja dibuat. Hal ini didukung dengan penelitian yang dilakukan oleh Susanti, A. E, \& Suwu (2016)menyatakan bahwa PBL menekankan pada aktivitas pemecahan masalah dalam pembelajaran. Melalui PBL aktivitas belajar siswa mengasah 
Budi Priyadi | Efektivitas Penerapan Model Problem Based Learning Terhadap Peningkatan Hasil Belajar Bola Voli

bagaimana cara memecahkan suatu permasalahan sehingga berimplikasi terhadap keterampilan berpikir kritis.

Model pembelajaran saintifik dalam implementasi kurikulum 2013 mengharuskan semua mata pelajaran untuk menggunakannya, tidak terkecuali mata pelajaran penjas. Model pembelajaran saintifik yang kami gunakan adalah problem based learning untuk meningkatkan hasil belajar teknik dasar service dalam permainan bola voli. Beberapa hasil penelitian yang sudah dijelaskan sebelumnya mengungkapkan bahwa dengan menerapkan model pembelajaran PBL secara signifikan dapat meningkatkan hasil belajar bola voli (Kurniawan, Rachman, \& Indahwati, 2021).

\section{SIMPULAN}

Proses belajar mengajar dalam mata pelajaran PJOK khususnya materi permainan bola voli memerlukan sebuah model pembelajaran sesuai anjuran kurikulum 2013 yang lebih menitikberatkan terhadap pendekatan ilmiah. Model problem-based learning (PBL) memberikan kontribusi yang signifikan untuk meningkatkan hasil belajar service dalam permainan bola voli, terbukti adanya peningkatan dari siklus 1 dengan nilai rata-rata siswa 72 dan siklus II dengan nilai rata-rata siswa 83 dari jumlah 32 siswa kelas IX.2 MTs Negeri 5 Kuningan, artinya sudah memenuhi nilai KKM 75. Persentase keberhasilan siswa mencapai KKM dari siklus 1 ke siklus II mengalami peningkatan peningkatan yang tinggi yaitu dari $59 \%$ menjadi $100 \%$.

\section{REFERENSI}

Amir, M. T. (2009). Inovasi Pendidikan Melalui Problem Based learning. Jakarta: Kencana Prenada Media Group.

Aqib, Z. (2010). Penelitian Tindakan Kelas Untuk Guru. Bandung: Yrama Widya.

Arikunto, S. (2010). Prosedur Penelitian Suatu pendekatan Praktek. Jakarta: Rineka Cipta.

Barrows, H. (1996). New Direction for Teaching and Learning "ProblemBased Learning in Medichine and Beyond; Abrief Overview." University School of Medicine: Jossey Bass Publishers.

Edens, K. M. (2000). Preparing problem solvers for the 21st century trhough problembased learning. College Teaching, 48(2), 55-60.

EdVisions. (2007). dVisions Schools @2006- 2007 Edvision. 
Ejin, S. (2016). Pengaruh model problem based learning (PBL) terhadap pemahaman konsep dan keterampilan berpikir kritis siswa kelas IV SDN Jambu Hilir Baluti 2 Pada Mata Pelajaran Ilmu Pengetahuan Alam. Jurnal Pendidikan, 1(1), 65-71.

Graham, R. (2010). UK approaches to engineering project-based learning. From Bernard M. Gordon MIT Engineering Leadership Program : Http:/ Www.Rhgraham.Org/RHG/Recent_publications_files/MIT\%20White\%20Paper\%20\%20UK\%20PjBL\%20April\%202010.Pdf.

Graham, R. (2012). chieving excellence in engineering education: the ingredients of successful change. London: The Royal Academy of Engineering.

Haigt, W., Kelly, R. , \& Bogda, B. (2005). roject-based learning: a natural fit with discance education. Online classroom. Academic Search Complete database.

Hamzah, B., \& Hadiana, O. (2018). Pengaruh Penggunaan Model Problem Based Learning Terhadap Keterampilan Passing Dalam Permainan Futsal. JUARA : Jurnal Olahraga, 3(1), 1. https://doi.org/10.33222/juara.v3i1.210

Kemendikbud. (2013). Materi Pelatihan Guru Implementasi Kurikulum 2013 Mata Pelajaran Pendidikan Jasmani Olahraga dan Kesehatan untuk SMP/MTs. Jakarta.

Kemendikbud. (2017). Silabus Mata Pelajaran Pendidikan Jasmani Olahraga dan Kesehatan SMP/MTs. Jakarta: Kementrian Pendidikan dan Kebudayaan.

Kurniawan, S. K., Rachman, A., \& Indahwati, N. (2021). Pengembangan Permainan Bola Besar (Bolavoli) Berbasis Problem Based Learning Untuk Meningkatkan Minat Belajar Peserta Didik Putri. Jurnal IImiah Mandala Education, 7(1), 49-56. https://doi.org/10.36312/jime.v7i1.1692

Mayasari, T., Kadarohman, A., Rusdiana, D., \& Kaniawati, I. (2016). Apakah Model Pembelajaran Problem Based Learning Dan Project Based Learning Mampu Melatihkan Keterampilan Abad 21? Jurnal Pendidikan Fisika Dan Keilmuan (JPFK), 2(1), 48. https://doi.org/10.25273/jpfk.v2i1.24

Muhson, A. (2009). Peningkatan minat belajar dan pemahaman mahasiswa melalui penerapan problem based learning. Jurnal Kependidikan: Penelitian Inovasi Pembelajaran, 39(2), 171 - 182.

Nurhasan. (2007). Tes dan Pengukuran Olahraga. Bandung: FPOK UPI.

Prayoga, M. F. (2021). Edu Sportivo. 2(1), 21-26.

Republik, D. R. [Departemen P. N. I. (2003). Standar Kompetensi: Mata Pelajaran Pendidikan Jasmani Sekolah Menengah Pertama dan Madrasah Tsanawiyah. Jakarta: Departemen Pendidikan Nasional Republik Indonesia. 
Slough, S. W., \& Milam, J. O. (2013). Theoretical framework for the design of STEM project based learning. In R. M. Capraro, Capraro, M. M., \& Morgan, J., STEM project-based learning: an integrated science, technology, engineering, and mathematics (STEM) approach (pp. 15-27). Rotterdam: The Netherland: Sense.

Sugiyono. (2013). Metode Penelitian Pendidikan (18th ed.). Bandung: Alfabeta.

Susanti, A. E, \& Suwu, S. E. (2016). Penerapan Pembelajaran Berbasis Masalah untuk Meningkatkan Ketrampilan Berpikir Kritis Siswa Kelas IX dalam Pelajaran Ekonomi. Jurnal POL YGLOT, 12(1), 66-81.

Suzianto, \& Damanik, S. (2014). Penerapan Model Problem Based Learning Dalam Meningkatkan Hasil Belajar Passing Bawah Bola Voli Siswa Kelas Viii-2 Smp Negeri 27 Medan Tp. 2018/2019. Jurnal IImu Keolahragaan, 18(1), 14-24. Retrieved from https://jurnal.unimed.ac.id/2012/index.php/JIK/article/view/14302

Tan, O. (2003). Problem Based Learning Innovation: Using Problem to Power Learning in 21st Century, thompson Learning.

Wagner, T. (2008). The global achievement gap: why even our best schools don't teach the new survival skills our children need-and what we can do about it. New York: Basic Books.

Wee Keng, M. A. K. (2002). Authentic Problem Based learning: Rewriting Business Education. Prentice Hall.

Woods, D. R. (1996). Problem-based learning for large classes in chemical engineering. Bringing problem-based learning.

Yudiana, Y. (2015). Implementasi Model Pendekatan Taktik dan Teknik dalam Pembelajaran Permainan Bola Voli pada Pendidikan Jasmani Siswa Sekolah Menengah Pertama. Kajian Pendidikan, 5(1), 95-114. 